Ewa Nowak

\title{
Tożsamość Todda. Mózg między filozoficzną neurosferą a literacką (meta)fikcją ${ }^{1}$
}

\section{Jak nawigować $w$ neurosferze, by nie utonąć?}

W dawnych, przeddarwinowskich czasach mózg i duch zdawały się tkwić w beznadziejnej aporii, a każde dictum naukowe, filozoficzne, literackie et cetera, usiłujące zaprowadzić między nimi pokój czy choćby rozejm, stawało się kamieniem obrazy dla „ducha”. W filozofii przełom zachodził bodaj najwolniej: żyła ona jeszcze idealizmem, najpierw gdy przez Europę przemykał duch romantyzmu, szybko wyparty przez twardo stąpający po ziemi pozytywizm, któremu znów wypadało stawić czoła - co też uczynił Edmund Husserl w rozprawie zatytułowanej Kryzys europejskiego człowieczeństwa a filozofia. Przełom w relacjach mózg-duch nabrał tempa dopiero za sprawą psychoanalizy (Friedrich Nietzsche, Sigmund Freud), tak zwanej fenomenologii drugiej fali ${ }^{2}$, spokrew-

1 Artykuł powstał w ramach grantu NCN Opus $9 \mathrm{nr} 2015 / 17 / \mathrm{B} / \mathrm{HS} 1 / 02381$ „Ewolucja jaźni: przyczynek do rewizji posthumanizmu”. Autorka składa Narodowemu Centrum Nauki podziękowania za wsparcie i sfinansowanie prowadzonych przez nią badań.

2 Można się domyślać, że wiążąc ekspresje cielesne (także mimikę twarzy) z somatycznym „Ich-Leib” i psychicznym „Ich-Organ”, Husserl [1973: 63] nie brał pod rozwagę jakiejkolwiek relacji pomiędzy „ja” ucieleśnionym i „ja” duchowym. 
nionej z egzystencjalizmem (Jean-Paul Sartre, Maurice Merleau-Ponty, Hermann Schmitz, Emmanuel Levinas), i pragmatyzmu (William James, John Dewey). To właśnie te nurty zagłębiały się w ludzki oraz nieludzki „ustrój cielesny” [Nietzsche 1995] w poszukiwaniu znamion kondycji ludzkiej, które rodzą się na sekretnym styku „materii myślącej” z „materią rozciągłą”, wnętrza z zewnętrzem, zmysłów z umysłem et cetera.

Nie znaczy to, że definitywnie rozstaliśmy się z Kantowskim pytaniem, „jak dalece jaźń może być niezależna od ciała” [Keller 2001: 183] ]', i myślimy o wspomnianych realnościach wyłącznie w kategoriach ontologiczno-funkcjonalistycznej „unifikacji” [Churchland 1989] oraz „umysłu ucieleśnionego" - a zatem ponad dychotomią przyroda/metafizyka i, w konsekwencji, ponad dychotomią determinizm/wolność [Gallagher 2005; Roth, Strüber 2016], wreszcie ponad redukcjonizmem. Jest on nieuchronnym skutkiem lapczywego przyswajania wybranych aspektów lub zgoła całości tej złożonej ontologii już to przez rzeczników skrajnego biologizmu [Churchland 2013], już to przez rzeczników romantycznego spirytualizmu [Koch 2012], który wierzy w samostanowienie mocą inteligibilnej lub emocjonalnej energii ludzkiego ducha. Podczas gdy wzajemne animozje i fobie redukcjonistów oraz „singularystów” [Dukaj 2010: 187] osiągają apogeum, na scenę wkracza kolejny punkt widzenia, zupełnie inaczej sytuujący jaźń i tożsamość człowieka w świetle jego ontologii wewnętrznej i zewnętrznej. Usytuowania tego nie sposób adekwatnie zdefiniować w kategoriach naturalnych (kosmos, physis, oikos), jak czyniły to antropologie od starożytności po pierwszą połowę $\mathrm{xx}$ wieku [zob. Renehan 1981; Gehlen 1986; Scheler 1987; Snell 2009]. Nabiera ono coraz więcej znamion trans-i posthumanistycznych, w miarę jak człowiek przetwarza istniejącą rzeczywistość łącznie z sobą samym oraz wytwarza nową mocą swej działalności technopoietycznej. To nowe stanowisko ontologiczne i epistemologiczne

Relacja ta będzie później eksplorowana między innymi przez Bernharda Waldenfelsa [2013].

3 Jeżeli odsyłacz odnosi się do pozycji obcojęzycznej, tekst zostaje przytoczony w moim przekładzie. 
wielokrotnie opisano w nauce, zaś na gruncie literackim wyraził je Jacek Dukaj: „Wszyscy funkcjonujemy w sieciach, w relacjach, w grach. Także sama nauka [...]. Tak się zawierają w sobie dziedziny serca: to, co publiczne; a na zewnątrz publicznego - to, co nieznane człowiekowi o nim samym nawet w jego prywatności” [Dukaj 2010: 187].

Lapidarnie tylko zarysowane tendencje do integralnego ujmowania neurosfery, również pod prąd jej rzekomo linearnej „historii naturalnej”, pozwoliły też filozofii wejrzeć w powiązania i analogie między rozwojem systemu nerwowego u człowieka i innych gatunków, co z kolei otworzyło pole dla wizji, utopii oraz narracji transhumanistycznych. Potykają się one jednak o te same ograniczenia, co dyskurs naukowy dążący do bezwarunkowego rozpoznania i ostatecznego uzasadnienia zjawisk, które z uwagi na swoje znaczenie powinny być wyartykułowane i zrozumiane, ale których źródła są niedostępne poznaniu. Narracja i rozumienie mogą się do nich odnosić tak, jak antyrealista odnosi się do referentu, traktując go raczej jako wytwór, założenie czy postulat języka. Autopoietyczna funkcja języka jest doskonale znana filozofii oraz literaturze. Do jej implikatów należą między innymi intertekstualność i metafikcja, pozwalające myśleć dalej niż nauka. Poprzestając na opowieści, interpretacji, a nawet czystej autokreacji, dyscypliny te wypowiadają się świadomie i odpowiedzialnie - w przeciwieństwie do kogoś, kto, święcie przekonany o prawdziwości czy słuszności własnego przekazu, kolportuje fakty „alternatywne” i postprawdy.

Zarówno nauka, jak i epistemologia mają nie lada trudność ze zrozumieniem zjawisk, których naturę można umownie określić jako „kwantową”. Polegają one z grubsza na tym, że rezultaty jakiejś aktywności, interakcji, współzależności et cetera - oczekiwane bądź nieoczekiwane - nie znajdują wytłumaczenia w kategoriach logiki przyczynowości i sprawstwa. Do takich zjawisk należy współzależność między mózgiem a organizmem, od poziomu molekularnego poczynając, relacja między organizmem a jego otoczeniem, wreszcie hybryda lub chimera, która może powstać z połączenia DNA bądź organów i układów (zwłaszcza nerwowych) dwóch obcych sobie gatunkowo organizmów, a także z połączenia 
organizmu z urządzeniami syntetycznymi lub organoidalnymi. Szczególną zagadkę przedstawia na nowo ucieleśniony umysł: w jej obliczu nauka nie pozwala jeszcze odpowiedzieć na pytanie, jak miałoby stać się możliwe zintegrowanie miliardów komórek nerwowych należących do organizmu macierzystego [Maturana, Varela 2012: 96] - tworzących byt o swoistych, indywidualnych właściwościach, funkcjach, wrażliwości, ekspresji, dynamice; byt otwarty na świat zewnętrzny na poziomie metabolizmu, percepcji, zachowania, interakcji, uczenia się, poznawania, wytwarzania obrazów, pojęć, idei, narracji, znaczeń, wartości et cetera $\mathrm{z}$ nowym organizmem, dając $\mathrm{w}$ rezultacie nowy byt. Nauce za to coraz bliżej do odpowiedzi na pytanie, na ile tak zwany awatar bądź sztuczna sieć neuronalna mogą reprezentować lub imitować umysł określonego indywiduum i w jakiej mierze taki twór mógłby zachować autonomię, odnaleźć się w interakcjach, wreszcie - ewoluować poprzez uczenie się [Kurzweil 2012] ${ }^{4}$.

\section{Wyobraźnia i metafikcja a poznanie}

Spektakularnej eksploracji neurosfery przez filozofię umysłu wychodzi naprzeciw literatura. Dopóki eksperymentalizm nie potrafi odpowiedzieć na pytanie, w jaki sposób realności organiczne oraz metafizyczne łączą się ze sobą i współdziałają, dopóty zdani jesteśmy na filozoficzne rozumienie takich zagadnień, a także na moc wyobraźni. Kartezjusz, Immanuel Kant i Hans Jonas dowodzą, że „to wyobraźnia uczy nas ujmować duszę i ciało jako jedność" [the imagination teaches us how to conceive the union of the soul and the body] [Merleau-Ponty 2001: 35]. Rozumienie osobliwych perypetii jedności, a przecież także dystynkcji mię-

Wbrew iluzjom roztaczanym przez kinematografię i literaturę SF możliwość odzwierciedlania, imitacji, adaptacji funkcji biologicznych (ludzkich) sieci neuronalnych przez sieci sztuczne jest ograniczona, nie mówiąc o odtwarzaniu zindywidualizowanych sposobów doświadczania, zachowań poznawczych i decyzyjnych, których nie sposób zaprogramować albo też w przypadku których nie sposób stwierdzić, czy program wykonuje te działania, do jakich został stworzony, czy może jednak „przerósł sam siebie”, nabrał znamion rzeczywistej, dynamicznej, ale także spontanicznej kognicji [Wiener 1990; Turkle 2006: 279]. 
dzy nimi - zwłaszcza w okolicznościach nowych i osobliwych, takich jak ksenotransplantacja, inteligentna protetyka (bionika) czy cyborgizacja - jest możliwe również za sprawą „metafikcji” i „metadramaturgii”, których metodologie sięgają czasów Miguela Cervantesa i Luigiego Pirandella. To nie deficyt dowodów naukowych, powierzchowność wiedzy potocznej czy domysły, którymi ludzie kompensują niedostateczne rozpoznanie oraz rozumienie rzeczywistości, ale działanie odpowiedniej narracji i dramaturgii literackiej sprawia, że mój umysł „zaczyna dziwić się i wątpić w status rzeczywistości, o której przeczytałem/przeczytałam" [I start wondering about the status in reality of what I have been reading] [Holland 2009: 78]. Także filozofia wspiera ten rodzaj poznania i rozumienia, jest bowiem doskonale świadoma tego, „iż człowiek nie zna «z natury» rozróżnienia ciała i duszy, ale musi się go uczyć. I podobnie $\ll z$ natury» nie jest mu znane rozróżnienie - a tym bardziej jedność - mózgu, umysłu i ich peryferii: tych również musi się dopiero uczyć” [Snell 2009: 39].

Jeśli idzie o metafikcyjną narrację literacką, interesuje mnie ona o tyle, o ile może wytrącać czytelnika ze stanu niezdolności do jakiejkolwiek narracji (dysnarrativia) w materii słabo jeszcze rozpoznanej przez naukę, a przy tym intensywnie zaprzątającej wyobraźnię zbiorową. Nawet jeśli ta ostatnia żywi się literaturą SF i figurami z gier komputerowych czy obrazów filmowych, jej aktywności towarzyszy refleksja. A ponieważ nie mówimy o refleksji opartej na wiarygodnych podstawach epistemologicznych lub ontologicznych, warto, by konstruowała ona kolejną wersję opowieści w sposób tym bardziej rozumiejący i świadomy, im bardziej osobliwa i zadziwiająca jest opowiadana „rzeczywistośc””.

Jedno z takich klasycznych filozoficznych ćwiczeń z zadziwienia nieznanym stanowi mit o statku Tezeusza, skłaniający przede wszystkim do namysłu nad tożsamością rzeczy, ale przecież także istot żywych i osób. Mówi nam ono bowiem, że temporalność, dziejowość oraz prawo przemijania wprawiają mikro-i makrotożsamość bytu w zadziwiającą dynamikę. Dotyka ona istotę ludzką w wielu wymiarach, od genetyki po autonarrację [Ricoeur 1991], która odsłania narratorowi „jego samego”, lecz jako coraz to innego. Narracja starająca się zgłębić tajemnicę z natury rzeczy ukrytego 
splotu ciągłości i zmiany lub tylko wypełniająca go jakąś nową treścią może posługiwać się elementami samoświadomej metafikcji ${ }^{5}$ wtedy, gdy „ja” narracyjne staje się histrionem tworzącym przekaz literacki. Do specyfiki metafikcji należy to, że „głos narratora nie jest zewnętrznym autorytetem potwierdzającym autentyczność przekazu, lecz jest to głos którejś z postaci” [the voice of the narrator is not an exterior authenticating authorial one; it is the voice of a character] [Hutcheon 1980: 63]. Poniżej omówię przykładowy przekaz tego rodzaju, czyli debiut T. Richarda Browna pt. The Face in the Mirror: A Transhuman Identity Crisis [2012]. Autor noweli, najwyraźniej nieznający arkanów metafikcji w zakresie, jaki bada teoria literatury, posłużył się jej metodą nieświadomie. Jego utwór zawiera wszak wątki trans- i posthumanistyczne, których prekursorów - uznanych pisarzy tworzących swoisty genre - można wskazać bez większego trudu, nawet jeśli w „samym sercu podobieństwa odsłania się nagle różnica", jak powiada Linda Hutcheon [1980: 63]. Pozorując realizm, przełamują oni konwencję „realistyczną"' $\mathrm{i}$ wkraczają na teren hiperrealizmu, gdzie szukają zasady własnego, nowego i przez nikogo jeszcze niespenetrowanego post-świata. Ten zaś pragnie być spójny i znaczący tym bardziej, im bardziej wymyka się czyjemukolwiek doświadczeniu, przechodząc do porządku, który z ludzkiego punktu widzenia jawi się jako chaos?.

5 Odsyłam tutaj do błyskotliwej interpretacji burleski z udziałem Flipa i Flapa pt. Our Relations dokonanej przez Zeno Gozo [2015].

6 Analogia z metafikcją nie może tu być ani pełna, ani oczywista. W noweli Browna narzuca się ona najpierw za sprawą strukturalnego podobieństwa narracji do prozy innych autorów, między innymi Franza Kafki, który zdania proste lączy zazwyczaj spójnikiem „i”, a także za sprawą narracji pierwszoosobowej z perspektywy doświadczenia wewnętrznego, „,introwertycznej”, „introspektywnej”, „autorefleksyjnej”, „autoreferencyjnej”, a przecież pozbawionej realnego „referentu" (por. studium Hutcheon [1980: 1], poświęcone metafikcji w literaturze, psychoanalizie, sztuce i filozofii).

7 To jednak nie liryczna i stylizowana na autobiografię narracja Browna, a bardziej epicka narracja Dukaja eksplikuje zasady założycielskiego chaosu, a także jego potencjał emancypacyjny: „Własne idee. Cokolwiek. Kanibalizm. Niewolnictwo. Wolny rynek. Demokracja. Tyrania. Teokracja. Anarchia [...] Czemu utożsamiasz chaos ze złem? To przesąd, bajkowy schemat. W chaosie, w bałaganie, w nieuporządkowanym ruchu milionów jednostek, w ślepej zbieraninie wszelkich możliwych poglądów, metod i celów - tam jesteś bezpieczna, tam zawsze 
Szereg spektakularnych przykładów współczesnej prozy antycypującej doświadczenie trans- i posthumanistyczne z perspektywy nowego lub zmodyfikowanego ucieleśnienia otwiera Franz Kafka [Fingerhut 1994; Kosik 1994; Gilman 2003: 12-18]. Wykorzystał on figurę reinkarnacji, a raczej przepoczwarzenia (Körperwechsel, Metamorphose) [Nida-Rümelin 2007: 31, 313] dorosłego mężczyzny w postać olbrzymiego stawonoga, aby unaocznić absurd i brutalność społecznej degradacji, alienacji, a wreszcie dehumanizacji ludzkiego indywiduum. Kumulacja tych czynników unicestwia Gregora Samsę z tragiczną nieuchronnością w taki oto sposób, że zostaje on „wycieleśniony” z ludzkiej powłoki cielesnej i natychmiast „wcielony” w nową, owadzią powłokę. Po nagłym zderzeniu dwóch skrajnie odmiennych egzystencji oraz usposobień kondycja owadzia z wolna wchłania ludzką wraz z tym, co dla niej najbardziej swoiste, a także osobiste dla tego oto indywiduum: pamięcią, wrażliwością, ekspresją, nawykami, upodobaniami. Człowiek okazuje się wewnętrznie i subiektywnie przywiązany do siebie, nawet jeśli doświadczał siebie i swego usytuowania w świecie jako ciężaru czy rutyny lub też był zawstydzany i marginalizowany z racji swego istnienia, aż po samounicestwienie (opowiadanie Głodomór).

A jednak absolutność owego przywiązania do własnej kondycji można zakwestionować, przywołując co najmniej dwa argumenty. Po pierwsze, fałszywe jest przekonanie, że przywiązanie do „siebie” wygenerowała ewolucja. Gdyby rzeczywiście tak było, subiektywne przywiązanie stałoby się obiektywnym przypisaniem. Z wyjaśnieniem przychodzi tu Friedrich Dürrenmatt,

będziesz miała dokąd uciec, zawsze ktoś cię ochroni. Chaos nie jest zdolny do wielkiego dobra, nie potrafi działać dla wielkich idei [...], nie zaprowadzi jednym dekretem szczęścia i dobrobytu na całej Ziemi - ale z tych samych przyczyn nie jest też zdolny do wielkiego zła, nie buduje obozów koncentracyjnych i łagrów, nie spuszcza bomb atomowych, nie zniewala narodów, nie przymusza ludzi do podłości. To wielkiego porządku winniśmy się bać [...] jedyne rozwiązanie to zdać się na chaos. Nie: przejmować władzę, zwiększać kontrolę i zaprowadzać utopię pod przymusem - ale: zrzec się władzy, oddać kontrolę nad człowiekiem temu, czego człowiek nie może kontrolować, szukać utopii w anarkii. Ujrzeli szczęście w chaosie, ja też, ja też chyba je widzę" [Dukaj 2010: 21, 516-517]. 
piewca „przedlogicznego i przedmoralnego”8 pramózgu, którego najbardziej archaiczną i zarazem anarchiczną część ludzkość dzieli $\mathrm{z}$ całą ziemską fauną:

Jestem przekonany, że mózg wcale się nie zmienił [das Gehirn gleichgeblieben ist]. Wlecze on ze sobą archaiczne lęki, wrogość, impulsywność. Uważam, że człowiek staje się z wolna zaprzeczeniem własnych, pierwotnych instynktów. Ta agresja, ten strach przed obcymi. Weźmy patriotyzm: odsłania on emocje cofające nas daleko przed czasy, gdy ewolucja mózgu raptownie przyspieszyła. Nagle mózg stał się naszym przekleństwem [dosł. przeciwieństwem - E.N.]. Innymi słowy: skłócił człowieka z nim samym, wtrącając go w biologiczny kryzys [hat den Menschen in einen Gegensatz zu sich selbst, in eine biologische Krise geführt]. Sądzę, że człowieczeństwo jest biologicznie zagrożone [die Menschheit als biologisch in Gefahr], i sam nie wiem, do czego to doprowadzi [...]. Wygląda na to, że człowiek właściwie nie dostaje do swojego własnego mózgu [der Mensch hält eigentlich sein eigenes Gehirn nicht aus]. [Dürrenmatt 1996: 115]

8 Podkopującego antropocentryzm, humanistyczny idealizm, mit postępu, „mit nauki”, a także naiwną wiarę w linearny bieg historii naturalnej [Schüller 2010: 108].

Zbliżone stanowisko prezentuje Hoimar von Ditfurth [1976] (porównywane później ze stanowiskiem Richarda Dawkinsa ze Ślepego zegarmistrza). Obaj z Dürrenmattem nawiązywali do tradycji psychoanalitycznej, Carl Gustav Jung także pisał bowiem o „niedopasowaniu do świata wewnętrznego, jak i zewnętrznego”, „prymitywizmie”, który stawia znak równości między „tym, co obce, a tym, co wrogie i złe”, wreszcie o tym, że „w postępkach narodów tkwią postępki jednostek: dopóki czyni coś jednostka, dopóty czyni to naród” [Jung 1974: 174-177]. Od „zwaśnienia” i „wrogości”, uwarunkowanych biologiczną specyfiką mózgu, niedaleko już do opisanych przez Tzvetana Todorova „zachowań manifestujących nienawiść lub pogardę dla jednostek o cechach zewnętrznych wyraźnie odbiegających od naszych; z drugiej strony pojawia się ideologia i doktryna ras ludzkich. Te dwie kwestie nie muszą być ze sobą powiązane [... ] tym niemniej, rasy porównuje się do gatunków zwierząt, domagając się między dwoma rasami ludzi dystansu podobnego temu, jaki występuje między końmi i osłami $[\ldots]$ wystarcza to do stworzenia oczywistej dla wszystkich granicy [...] Solidarność między rasą i kulturą sprawia, że rasy mogą prowadzić ze sobą wojny” [Todorov 2000: 64-65]. 
Drugim powodem jest eksperymentalizm, od czasów zwrotu modernistycznego śmiało eksplorujący możliwości mózgu ludzkiego i zwierzęcego. Literatura obfituje w wizje ukazujące spektakularną groteskę rozgrywającą się w laboratoriach medycznych podobnych temu, które należało do doktora Preobrażeńskiego:

- Tak! - zaryczał Filip Filipowicz. - Tak! Jeśli tylko nieszczęsny pies nie zdechnie mi pod nożem, a widział pan, jaka to operacja [...]. Można wszczepić przysadkę Spinozy albo jakiegokolwiek innego czorta i przerobić psa na coś niebywałego. Pytanie tylko, po jakiego diabła? [...] Po co sztucznie fabrykować Spinozę, kiedy zwykła baba może go urodzić w każdej chwili. Przecież madame Łomonosowa urodziła w Chołmogorach tego swojego wspaniałego. Ludzkość, doktorze, sama zatroszczy się o to w trybie ewolucji, uporczywie wyodrębniając z nikczemnej masy przeciętności dziesiątki niezwykłych geniuszy, którzy są chlubą naszej planety... [Bułhakow 1989: 82]

Dziś progresywne utopie znalazły kontynuację w tak zwanych dystopiach, których groteskowość z trudem przebija się spod namaszczonych przez naukę wizji cyfrowego trans- i posthumanizmu. Jednak skłócony z mózgiem i manipulujący nim duch modernistyczny, a dziś - postmodernistyczny, z mózgiem nie tylko pogodzony, ale też coraz bardziej utożsamiony, miały prekursora w duchu archaicznym, który postrzegał ten ludzki narząd w sposób może najbardziej adekwatny: jako unikalny „organ duszy rozumnej”, którego znaczenie dla ludzkiej kondycji (bardziej aniżeli dla ludzkiego organizmu), oddaje określenie hegemonikon [Rocca 2003], „organ hegemoniczny”". Mózg uzyskał taki status za sprawą przełomowych badań dokonanych przez Galena i jego

W De usu partium Galen opisał ten narząd jako centralny ze wszech miar, nie tylko z punktu widzenia funkcji życiowych: „Substancja mózgowa jest tożsama z nerwami, zdolna odbierać wrażenia, wytwarzać obrazy i rozumieć myśli” [Rocca 2003: 81] (zob. też Bruno Snell o „duchowych narządach thymos i noos” [Snell 2009: 37]). Swe stanowisko przeciwstawił Galen również tym wszystkim, którzy nie potrafiąc wyjaśnić fizjologicznie takich funkcji jak pneuma, psyche, a nawet dusza rozumna, łączyli je z eterem, fluidem et cetera; tymczasem „aktyw- 
niezłomnego poglądu Galenus contra mundum. Przyjął tak zdecydowane stanowisko nie bez powodu, gdyż za siedzibę intelektu wielu uważało wówczas serce, a wśród nich między innymi Empedokles, Arystoteles, Diokles, Praksagoras i stoicy.

Należałoby się spodziewać, że dokonane w Aleksandrii odkrycie nerwów i ich mózgowego pochodzenia stanie się dla wszystkich oczywistością i nikt już nie będzie podważał tego, że to mózg jest siedzibą intelektu. Tymczasem w obronie stoickiego dogmatu stanął Chryzyp, powołujący się na autorytety medyczne sprzed półwiecza, w tym na Praksagorasa. [Longrigg 1993: 61; por. 1988] ${ }^{11}$

Unikalne zdolności związane z działaniem mózgu, w tym jego względna niezależność, znana jako dysocjacja lub wycieleśnienie i oderwanie od bezpośredniości propriocepcji, otwierają niezmierzone przestrzenie dla swobodnej gry wyobraźni [Holland 2009: 55]. Może ona dopomóc w zrozumieniu, czego doświadcza istota, której umysł „budzi się” w nowym ucieleśnieniu, z wolna odkrywając drogę, która przywiodła go do tego położenia na skutek okoliczności losowych. Metodologia literackiej metafikcji wydaje się tu bardziej na miejscu aniżeli metodologia eksperymentu myślowego stosowanego w nauce. Główną przeszkodę $\mathrm{w}$ takim eksperymencie stanowi brak przesłanek pozwalających mówić o zachowaniu nawet elementarnej ciągłości doświadczenia (najpierw w rozumieniu proprioceptywnym) pomiędzy ucieleśnieniem pierwotnym a wtórnym. Innymi słowy, nie znamy odpowiedzi na pytanie o ciągłość tożsamości w rozumieniu psychicznym w kontekście nieciągłości tożsamości somatycznej, co jest kwestią wielce skomplikowaną w świetle jej non-kartezjańskiego, psychosomatycznego, holistycznego pojęcia. Mamy raczej powody przypuszczać, że skoro cały szereg znanych człowiekowi

ności duszy rozumnej obejmują też wyobraźnię, rozumowanie i pamięć, których nie sposób umiejscowić w żadnej określonej partii mózgu” [Rocca 2003: 245].

Nie rozważam tu poglądów o ponadnaturalnym pochodzeniu wyższych fakultetów duszy, powszechnie znanych, a niewiele wnoszących do naturalistycznej metodologii przyjętej w tym artykule. 
doświadczeń, naruszających tę drugą, somatyczną tożsamość (np. amputacja ${ }^{12}$, transplantacja, deformacja, protetyka etc.) stanowi ogromne wyzwanie dla tożsamości jako takiej, to opisany niżej, fikcyjny przecież, przykład zradykalizowałby to wyzwanie do rozmiarów, których - mimo akrobatyki wyobraźni - nie jesteśmy w stanie odmalować sobie żadną miarą. Również kategorie pozwalające uchwycić doznanie dwoistości, na przykład „dywiduum”, skądinąd wpisane w pojęcie „in-dywiduum” i jego epistemologię, mogą okazać się nieprzydatne w heurezie doświadczenia radykalnie transcielesnego (wymiana całego ucieleśnienia na inne, niekoniecznie ludzkie) [Haraway 2007], nawet w świetle afirmatywnej ontologii, epistemologii, wreszcie - oceny etycznej. Matthew Ratcliffe podkreśla, iż nie znaczy to, że doświadczenie „ciała obcego” jest nieznane ludzkości - zaobserwowano je w niektórych przypadkach schizofrenii, powiązanej z zaburzoną propriocepcją. Pacjenci opisują wewnętrzne doznania, takie jak „ruch, dotyk lub nacisk wewnątrz ciała bądź na jego powierzchni; coś jakby prąd czy mrowienie; ciepło; kurczenie się i rozszerzenie, ciężar albo lekkość, spadanie albo pustkę, sztywnienie albo rozluźnienie” [Ratcliffe 2007: 193]. Schizofrenikom dane jest w całej okazałości (łącznie z towarzyszącym temu uczuciem wstrętu) przeżycie, którego doświadcza Samsa ukłuty przez nieznany mu wcześniej ból: „[... ] chciał obmacać to miejsce jedną z nóg, ale zaraz ją cofnął, gdyż przy dotknięciu przeszył go zimny dreszcz [... ] piekący ból, którego doznał, pouczył go, że obecnie dolna część jego ciała jest prawdopodobnie najbardziej uczulona” [Kafka 1994: 645]. Schizofrenicy znają nie tylko poczucie obcości, ale i nieobecności własnego ciała, a także współobecności lub dominującej obecności „ciała obcego”, odpychanego przez „prawdziwe ja”; znajome im są rozmaite maski i przebrania, którymi „cudze” próbuje przesłonić i ubezwłasnowolnić „własne” [Müller 1996: 234]; wreszcie przetarte są dla nich szlaki prowadzące ze świata realnego w irrealny, wyobcowany, spiskujący i wrogi. Perspektywa ciągłego pierwszosprawne organy jako „ciało obce”, fetyszyzuje kikut po amputacji et cetera [Lingis 2005]. 
osobowego doświadczenia to być może największe wyzwanie stojące przed każdym, kto chciałby powiedzieć cokolwiek wiarygodnego o sobie w stanie tej osobliwej transcielesności, która zamyka dostęp do własnego ciała od wewnątrz, jako dostęp natury najbardziej intymnej. Oprócz fenomenologicznych warunków ciągłości w sferze doświadczenia wewnętrznego badacze tacy jak Thomas Fuchs analizują warunki autopoietyczne, pamięć somatyczną, synchronizację i desynchronizację świata wewnętrznego z zewnętrznym, poczucie bycia sobą oraz jego ustanie (mimo zachowanych wspomnień i zdolności kontynuowania autonarracji) również w kontekście neurologiczno-psychiatrycznym [Fuchs 2017]. Zrekonstruowane poniżej projekcje, przedstawiające doświadczenie zdrowej ludzkiej osoby, która po serii tragicznych zdarzeń uzyskuje nowe, tylko częściowo ludzkie ucieleśnienie, można interpretować właśnie z perspektywy piśmiennictwa fenomenologiczno-psychiatrycznego, a także - do czego starałam się przekonać wyżej - z perspektywy wybranych dzieł literackich, swobodnie eksplorujących podobną problematykę.

\section{The Face in the Mirror T.R. Browna}

W powieści Browna Todd Herschel budzi się z narkozy i krok po kroku, najpierw za sprawą odbicia w lustrze, uświadamia sobie swoje nowe położenie: „,...] niespełna dwie stopy ode mnie stała postać o zielonych, wąskich jak u kota oczach i ciemnoszarym futrze, najwyraźniej kobieca [a felis female] [...]. Gdy obcy z lustra podniósł rękę, zrozumiałem, że patrzę na własne odbicie” [Brown 2012: 17]. Dla wielu doświadczeń Todda z łatwością wskazać można analogie w autobiograficznych relacjach pacjentów poddanych amputacji bądź transplantacji, którzy uczą się rozpoznawać i oswajać własne fizjonomie, drastycznie przez te zabiegi odmienione [Swindel 2007; Bluhm, Clendenin 2009: 93-94; Nowak 2017]. Bohater ma za sobą zarówno amputację „całego dawnego ucieleśnienia" [you have had your entire old body amputated], jak i transplantację nowego. W pierwszej chwili własny widok w lustrze przerasta go psychiczne, ale już wkrótce podejmuje wyzwanie („musisz zmierzyć się z tym, czym i kim jesteś 
teraz”), „przestaje zaprzeczać prawdzie” [Brown 2012: 19] i rozpoczyna mozolną naukę układania się z nowym ciałem, a dokładniej: $\mathrm{z}$ transgatunkową hybrydą ciała ludzkiego i kociego o kobiecych znamionach płciowych, z gatunku tak zwanych neohominidów $[\text { Neohumans }]^{13}$.

Z czasem na jaw wychodzą prawdziwe okoliczności całej sytuacji. Okazuje się, że Todd uległ fatalnemu wypadkowi, który niemal doszczętnie zniszczył jego ciało. Ocalał zeń tylko mózg. Coleen, żona bohatera, wybierając między „cyborgizacją” a transplantacją jego narządu do nowego ciała, zdecydowała się na tę drugą możliwość. W bieżącej ofercie ciał zastępczych dostępne były wyłącznie neohominidy, a mózg jako transplant jest organem co najmniej tak samo wrażliwym jak serce - należy go przeszczepić możliwie najszybciej. Jak tłumaczyła później Coleen, „[...] przecież to wciąż jesteś ty [Todd]. Twoja tożsamość skupiona jest w mózgu, prawda?” [Brown 2012: 39]. Osobiste doświadczenia Todda związane z nowym ucieleśnieniem okazały się mniej spektakularne, zbyt głęboki był bowiem dysonans pomiędzy reprezentacją własnego ciała wyniesioną z poprzedniego wcielenia a bieżącą percepcją nowej powierzchowności:

Choć w lustrze nie widziałem już monstrum, nie potrafiłem zobaczyć tam siebie ani nawet nowego siebie [I didn't even see the new me]. Zobaczyłem kogoś obcego i poczułem, że przechodzą mnie ciarki. Mimo wszystko w głębi ducha [intellectually] wiedziałem, że tam, za tymi oczyma, jestem ja. [Brown 2012: 232]

Pomijając naiwne, pretensjonalne, monotonne i niewiele wnoszące do dziejów literatury partie debiutanckiej noweli Browna (której nie zamierzam porównywać z dziełami Kafki, Michaiła Bułhakowa czy Dürrenmatta), autorowi udało się wyartykułować kilka trafnych intuicji, zwłaszcza w odniesieniu do ograniczonej

Casus „posthumów” wystąpił wcześniej także w prozie Dukaja wraz z intrygującym umocowaniem: „Otóż nie żadne cyber-ideały, nie Technologiczne Osobliwości i szatańskie AI, lecz prosty rachunek ekonomiczny wypycha nas z gnoju w ducha" [Dukaj 2010: 21]. 
roli mózgu w rozległym i bogatym pejzażu indywidualnej tożsamości człowieka. Można bowiem przyjąć, że zarówno realność, którą uważamy za żywe, organiczne ciało, jak i realność, którą (za Nietzschem oraz Husserlem) uważamy za "ciało przeżywane”, są przeniknięte peryferyjnym, względnie autonomicznym układem nerwowym [por. Brown 2012: 113] zdolnym działać nawet po odłączeniu od mózgu („even when disconnected from the central nervous system”). „Twoje nowe ciało zachowało własną pamięć i nieraz odpowie ci w sposób, jakiego się nie spodziewasz" [Brown 2012: 24], uświadamia Toddowi jego konsultantka medyczna. Wypowiedź ta świadczy o tym, że Brown nie postrzega ciała jako bezwolnego narzędzia, pojemnika na mózg i tożsamość czy hardware’u, który służyłby jedynie realizacji ludzkiej kognicji [Gärtner 2013: 340], a sam nie posiadałby znaczenia czy nawet okazywałby się kulą u nogi dla bardziej lotnego ducha. „To raczej mózg stanowi hardware, w którym należy odnaleźć software" [Brown 2012: 113-114], by móc go ewentualnie „skopiować”, symulując pracę neuronów i „molekul” [Brown 2012: 113] sztucznej inteligencji. Właśnie taki rodzaj „cyborgizacji” mężowskiego mózgu odrzuciła Coleen, wybrawszy transplantację do nowego ciała. Ciało - sugeruje Brown - jest bytem daleko bardziej złożonym, autonomicznym i naznaczonym osobistym doświadczeniem, aniżeli wydaje się to rzecznikom tożsamości sytuowanej wyłącznie w mózgu (należy do nich Coleen) oraz entuzjastom cielesności „wielokrotnego użytku”, a zwłaszcza bezcielesności celebrowanej współcześnie jako emancypacyjny efekt cyborgizacji. W spójnym skądinąd wywodzie Browna mało przekonująco brzmi uwaga, że „znacznie więcej czasu pochłonie twoja [tj. Todda] psychoterapia aniżeli rehabilitacja fizyczna, tym niemniej powieść powinny się obie” [Brown 2012: 115]. Terapeuci i technolodzy stają przed ogromnym wyzwaniem, zwłaszcza, że sam zainteresowany przypuszcza, iż „przeniesienie mózgu do nowego ciała może skutkować obłędem [insanity]" [Brown 2012: 114 $]^{14}$.

14 „To nie jest przesądzone - pociesza Todda asystentka - problemy mentalne mogą minąć” [Brown 2012: 114]. 
Zgodnie z fabułą powieści Browna ludzki mózg ulokowano w ciele na wpół zoomorficznym i na wpół antropomorficznym, co musi się przekładać na jego funkcjonowanie oraz zachowanie. Opisując ich formy w rytmie odkryć dokonywanych przez bohatera, Brown przyjmuje konwencję transhumanistyczną ${ }^{15}$. Jest to jeden z najbardziej wartościowych walorów jego prozy, zdradza bowiem empatię autora wobec „innego” i sympatię dla pokrewieństwa między mózgiem ludzkim a zwierzęcym. Wychodzi ono na jaw w eksperymencie myślowym, który Brown zrelacjonował w swej noweli. Eksperyment polega zaś na tym, że buduje się tu stopniowo - na podstawie sekwencji prawdopodobnych (lub możliwych do zrealizowania w niedalekiej przyszłości) doświadczeń - jednolitą, hipotetyczną samoświadomość oraz tożsamość międzygatunkowego indywiduum, wyposażonego w ludzki mózg i częściowo tylko antropomorficzną cielesność, sensomotorykę et cetera. Ponadto, w warunkach tej dość radykalnej metamorfozy psychofizycznej ${ }^{16}$ (choć nie aż tak radykalnej jak „przemiana” Kafki), eksploruje się krok po kroku plastyczność ludzkiej psychiki, pośrednio zaś (albowiem bezpośrednia eksploracja wymagałaby przeprowadzenia badań klinicznych) analizowana jest hipoteza o plastyczności ludzkiego mózgu. Brown przeprowadza

Pozbawioną wszak groteski i satyry, charakterystycznych dla Bułhakowa: „Powiedz mi, proszę, Szarikow - zaczął Bormental - jak długo jeszcze będziesz latał za kotami? Wstyd! Przecież to po prostu skandal! Dzikus! [...] Szarikow wlał sobie w gardło zawartość kieliszka, skrzywił się, przyłożył do nosa kawałek chleba, powąchał, a następnie połknął, przy czym łzy napłynęly mu do oczu" [Bułhakow 1989: 65-68]. Z kolei proza Browna wydaje się interesująca o tyle, o ile monotonne, pierwszoosobowe narracje i toczone w najzwyklejszym języku dialogi znamionują imponującą świadomość - a może raczej naturszczykowską wyobraźnię psychosomatyczną - u jej autora (na temat psychosomatyzmu zob. Helen F. Dunbar [1948]).

Połączenie mózgu z nowym ucieleśnieniem stanowi daleko bardziej rozległą, w zasadzie całkowitą, przemianę mentalną, funkcjonalną, egzystencjalną i społeczną, czego żadną miarą nie oddaje redukcjonistyczne określenie „psychofizyczny”, wszak ,ja jestem mym ciałem”, powiada Merleau-Ponty. Elementem metamorfozy Todda jest między innymi zmiana płci, stająca na przeszkodzie jego życiu intymnemu. „Byłem mężczyzną”, wyznaje. „Byłem żonaty z kobietą i pociągały mnie kobiety. Teraz pociągają mnie kobiety i kocie samce" [Brown 2012: 240]. 
swój eksperyment myślowy bez cienia tak zwanego antroponegacjonizmu, czyli apriorycznego odrzucenia istnienia wspólnych cech ludzi i zwierząt. Antroponegacjonizm oznacza umyślną ślepotę na przypominające cechy ludzkie właściwości zwierząt lub te nasze właściwości, które przywodzą na myśl cechy zwierzęce; odzwierciedla przeddarwinowską antypatię wobec głębokich podobieństw w zachowaniu ludzi i zwierząt, które dostrzega każda osoba o otwartym umyśle [Waal 2013: 91]. Obok metamorfozy fizycznej oraz wizerunkowej Todd przechodzi metamorfozę psychiczną i duchową, a nade wszystko tożsamościową:

Lepiej nie szukać podobieństw z innymi pacjentami, którzy przeszli transplantację [...]. Tak potężna wyrwa w jaźni [as for loosing yourself, with as extensive], jaką wywołała transformacja, musiała wstrząsnąć twoim poczuciem tożsamości [your sense of self is going through serious revision]. Czy słyszałeś kiedyś o transhumanizmie? [...] Nie... [Brown 2012: 87]

Choć Todd nigdy o transhumanizmie nie słyszał, po kilku miesiącach doświadczeń natury psychosomatycznej i somatoestetycznej dochodzi do przekonania, że dzieli „duszę” z poprzednią użytkowniczką swojego nowego ciała („sharing halves of the same soul”) [Brown 2012: 326], ale jednocześnie nie przestaje być - wszak tylko w odczuciu subiektywnym - osobą, za jaką uważał siebie, nim uległ wypadkowi. Odmienne są wrażenia Coleen, która niemal od początku całego procesu metamorfozy dostrzega w Toddzie monstrum [monster]: „pokaż im, że jesteś osobą” [Brown 2012: 370]. Percepcja jest silniejsza od jej wiary, że to „wciąż on” [Merleau-Ponty 1964], staje się czymś na kształt (między)ludzkiego probierza człowieczeństwa, a nawet imperatywu w transludzkim społeczeństwie, do którego dołączył Todd Herschel. W niezwykłym bogactwie jego perypetii uderza jednak pewne ubóstwo. Idzie tu o relację Todda z Coleen, która przywodzi na myśl bratersko-siostrzaną zażyłość między Gregorem i Grete Samsa, rozpadającą się w obliczu metamorfozy. Todd także otrze się o samobójczą depresję, gdy straci najbliższą mu osobę. Jego losy nie mają jednak w sobie tamtej fatalnej, Kafkowskiej alchemii. Czuwa nad 
nimi machina administracyjna, kliniczno-terapeutyczna i technologiczna, ale jednocześnie to właśnie ona jest źródłem ubożenia jego egzystencji. Jeśli nawet mózg Todda skopiowano, by stworzyć awatara, który współpracuje z oryginałem („watching what my avatar saw on her computer") [Brown 2012: 424] i który mógłby funkcjonować niezależnie od niego na wypadek komplikacji potransplantacyjnych, to przecież „życie umysłowe opiera się na doświadczeniu cielesnym”, podkreśla Richard Shustermann [2012: 105].

„Myślimy i czujemy naszymi ciałami, zwłaszcza tymi jego częściami, które tworzą mózg i system nerwowy" - powiada filozof [Shustermann 2012: 105]. To ciało otwiera każdej żywej istocie dostęp do niezbywalnego, niejednokrotnie dynamicznego oraz zaskakującego - a przy tym oferującego zadziwiający potencjał autopoietyczny - doświadczenia siebie. Żadna forma życia syntetycznego i żaden algorytm nie odtworzą, a tym bardziej nie zastąpią, życia w jego organiczno-zmysłowym potencjale i bogactwie, w jego interaktywnej obecności w świecie, karmiącej umysł, wreszcie - w jego wymiarze egzystencjalnym, pozwalającym odczuwać gorycz melancholii i bezsensu, doskwierających w tej samej mierze bohaterowi noweli Browna, co Gregorowi Samsie, gdy w „posępną pogodę" spogląda przez szybę na ulicę, którą donikąd go już nie zaprowadzi [Nabokov 1980], i zapada w $\operatorname{sen}^{17}$.

Czy zastosowane tutaj - na tyle, na ile pozwoliła objętość artykułu - metodologie fenomenologiczne i dyskursywno-literackie wnoszą coś nowego do zrozumienia doświadczeń transgatunkowych? Michel Foucault wiele lat temu, w Stowach i rzeczach, dał do zrozumienia, że nowożytna antropologia filozoficzna nastała za późno, gdy już definitywnie wyczerpały się taksonomie, reprezentacje i klucze pojęciowe zdolne adekwatnie opisać kondycję ludzką, należącą wszak - jak ujął to Georg Wilhelm Friedrich Hegel w Fenomenologii ducha - również do „zwierzęcego królestwa ducha”. Owszem, zarówno metodologie, jak i samo przebudzenie w ciele owada było snem, choć w opowiadaniu czytamy: „To nie był sen". 
przedmiotowe doświadczenie tranzycji między ucieleśnieniem pierwotnie ludzkim a wtórnie zwierzęcym, w której vehiculum ciągłości stanowi ten sam mózg jako fenomen daleko bardziej zindywidualizowany i złożony, niż można to wyrazić słowem „psychofizyczny”, wnoszą coś o tyle nowego, że Foucault nie badał doświadczenia konfrontacji subiektywnego ducha w ludzkim potencjale $\mathrm{z}$ równie subiektywnym duchem oraz doświadczeniem osobnika reprezentującego inny gatunek (obcy/xenos pod względem transplantologiczno-immunologicznym, ale już niekoniecznie pod względem po trochu sztucznie podtrzymywanych przez nauki o życiu różnic w ludzkiej i nieludzkiej „architekturze” ucieleśnienia). O ile upłynnienie wspomnianych różnic na poziomie organiczno-fizjologicznym, a nawet funkcjonalnym, jest coraz częściej obrazowane w literaturze pięknej i filozoficznej, które wytwarzają tym samym brakujące reprezentacje, o tyle upłynnienie różnic na poziomie doświadczenia, psychiki, a wreszcie - ducha nadal leży w sferze niedostępnej dla jakiejkolwiek „leksykografii” i „systemu fleksyjnego”, jak powiedziałby Foucault. Sfera ta nie pokrywa się z „historią naturalną” i nie może czerpać z jej leksykografii, tak intensywnie ostatnio rozwijanej na gruncie studiów transhumanistycznych. W dziedzinie tej mamy chwilowo do czynienia $\mathrm{z}$ „samoreprezentującą się reprezentacją” [Foucault 2006: 217] i powielaniem bądź cytowaniem reprezentacji. Rzecz w tym, że nawet jeśli uznać poznanie ludzkiego, holistycznie rozumianego potencjału za kompletne (co nie jest prawdą), to niekompletne - by nie rzec: szczątkowe - pozostaje nasze poznanie holistycznego potencjału zwierząt, łącznie z prymatami. Nie dysponujemy bowiem warunkami poznawczymi, które pozwalałyby nam odtworzyć ich reprezentacje siebie, świata, w którym żyją, wreszcie świata dzielonego przez człowieka i zwierzę; nie dysponujemy narzędziami, które pozwoliłyby przekładać ich reprezentacje na nasze ${ }^{18}$. Powstaje tutaj pytanie, czy mózg, być

Dotyczy to również narzędzi samokontroli u ewentualnych organizmów hybrydowych. Samokontrola ta ma źródło wewnętrzne, umysłowe, i przy całej płynności i umowności tej dystynkcji - z trudem, jeśli w ogóle, mogłaby objąć swoje nowe uzewnętrznienie, czyli ciało. W tym względzie Brown nie pozostawia złudzeń: „zobaczysz, że odruchowo będziesz robić rzeczy, których nigdy wcześniej 
może przy wsparciu technologii, mógłby przynajmniej w jakimś stopniu rozwinąć wspólne warunki, umożliwiające wytworzenie reprezentacji odzwierciedlających doświadczenie zunifikowane, nieredukowane ani tylko do ludzkiego, ani tylko do tego, które jest właściwe innemu gatunkowi; a ponadto obejmujące jakościowo nowe, osobnicze doświadczenia transgatunkowego „dywiduum"19 [Joraschky, Arnold 1998: 105], które stanowi ewidencję dla „bycia raczej kimś niż kimkolwiek lub zgoła nikim [... ]. Oto jeden z paradoksów dominacji ciała nad jaźnią" [Latimer 2009: 54-55]. Rodzi się również kolejne pytanie: po co mielibyśmy do tego dążyć? Jedyna zasadna odpowiedź, jaka przychodzi mi do głowy, to lepsze zrozumienie i poznanie działania mózgu człowieka oraz zwierząt w nieznanych jeszcze nikomu obszarach plastyczności, którą być może wspomaga nasze wspólne, ewolucyjne, kiedyś negowane, a dzisiaj powszechnie afirmowane dziedzictwo. Takie poznanie i rozumienie jest z pewnością niezbędne do poprawy położenia zwierząt $\mathrm{w}$ przeciągającej się ponad ich miarę epoce antropocenu. $U$ jego podstaw leży fałsz legitymizowany przez modele, konwencje oraz reprezentacje wykluczające zaistnienie świata zwanego „zoopolis” [Donaldson, Kymlicka 2011]. Wśród pozytywnych zastosowań dla adekwatnych reprezentacji widziałabym abolicję owych modeli i konwencji, a także przyznanie praw zwierzętom; byłabym jednak wstrzemięźliwa co do eksperymentów transhumanistycznych. Zachowałabym też ostrożność, jeśli idzie o poszukiwanie archaicznych wzorców dla umysłowego powinowactwa ludzi oraz zwierząt $w$ dawnych lub odmiennych kulturach, które rzadko - jeśli w ogóle - podejmują zagadnienie umysłowej suwerenności jednych i drugich, w moim przekonaniu niezbywalnej. Tym bardziej więc ambiwalentna jest wymowa zna-

nie robiłeś, a trudniej ci będzie robić rzeczy, które zwykłeś robić kiedyś [...] To trochę przerażające. Jakbym był pod kontrolą czegoś innego [like something else is controlling me]”, „[...] to, co na zewnątrz, nie jest już ludzkie; ale to, co w środku, jest wciąż ludzkie" [Brown 2012: 24, 65].

19 Badając bieżące doświadczenie cielesne i umysłową reprezentację ciała w kontekście schizofrenii, Peter Joraschky i Stefan Arnold podkreślają, że „poczucie tożsamości rodzi się za sprawą autoreprezentacji, nadających ciągłość i spójność przeżywaniu pomimo sprzecznych doświadczeń" [Joraschky, Arnold 1998: 105]. 
nej analogii z II księgi Państwa, gdzie Platon przypisuje strażnikom zdolności „psów dobrej rasy” [Platon 1958: 375B] ${ }^{20}$. Suwerenność, rozdzielność oraz różnicę można uważać za słaby kontrargument wobec radykalnie posthumanistycznej etyki (posthumanist ethics), która wymaga „erozji pojęć takich jak wyjątkowość człowieka i struktur wiedzy uprzywilejowujących człowieka względem wszystkich innych form życia” [Fay 2008: 41]. Podkreślam jednak, że chodzi o zachowanie różnic i specyfiki, a nie hierarchii i hegemonii. Rzetelna dyskusja naukowa musi uwzględniać wszelkie „za” i „przeciw”.

\section{Bibliografia}

Bluhm Carla, Clendenin Nathan (2009), Someone's Else Face in the Mirror, Praeger, Westport [Wielka Brytania].

Brown T. Richard (2012), The Face in the Mirror. A Transhuman Identity Crisis, edycja własna (Paperback, bez danych edytorskich).

Bułhakow Michaił (1989), Psie serce, przeł. Irena Lewandowska, Iskry, Warszawa 1989.

Churchland Patricia (1989), Neurophilosophy: Toward a Unified Science of the Mind-Brain, A Bradford Books, MIT Press, Cambridge [USA].

Churchland Patricia (2013), Touching a Nerve: The Self as Brain, W.W.

Norton \& Co., New York [USA].

Deane Samantha, Shuffelton Amy (2016), Plato and the Police:

Dogs, Guardians, and Why Accountability Is the Wrong Answer, „Educational Studies”, vol. 52 (6), s. 491-505.

Ditfurth Hoimar von (1976), Der Geist fiel nicht vom Himmel. Die Evolution unseres Bewusstseins, Hoffmann \& Campe, Hamburg [Niemcy].

Donaldson Sue, Kymlicka Will (2011), Zoopolis: A Political Theory of

Animal Rights, Oxford University Press, Oxford [Wielka Brytania].

W antycznych kulturach Morza Śródziemnego figura psa występowała w kontekście społecznym, a także sakralnym i symbolicznym przez długi czas, aż wreszcie słowa „pies” i „suka” stały się obelgami dla człowieka oraz synonimami życia poniżej ludzkich standardów, co podkreśla Cristiana Franco [2014]. Grecy znali tabu związane z nadawaniem psom imion ludzkich. „Psy zadomowiły się w środowisku człowieka tak bardzo, że zaczął on odczuwać potrzebę podkreślania ich nie-ludzkiej kondycji [their nonhumanness needs to be emphasized] [...]. Mogą naruszać granice między człowiekiem i zwierzęciem, co z kolei powoduje dyskomfort [...], mogą też zaatakować” [Deane, Shuffelton 2016: 491-505]. 
Dukaj Jacek (2010), Król Bólu, Wydawnictwo Literackie, Kraków.

Dunbar Helen F. (1948), Synopsis of Psychosomatic Diagnosis and Treatment, Mosby, St. Louis [USA].

Dürrenmatt Friedrich (1996), Dramaturgie des Denkens. Gespräche 1988-1990, red. Heinz Ludwig Arnold, Anna von Planta, Jan Strümpel, Diogenes, Zürich [Szwajcaria].

Fay Jennifer (2008), Seing / Loving Animals: André Bazin's Posthumanism, „Journal of Visual Culture”, vol. 7 (1), s. 41-64.

Fingerhut Karl-Heinz (1994), Die Verwandlung, w: Franz Kafka. Romane und Erzählungen, red. Michael Müller, Philipp Reclam, Stuttgart [Niemcy].

Foucault Michel (2006), Stowa i rzeczy. Archeologia nauk humanistycznych, przeł. Tadeusz Komendant, Wydawnictwo słowo/ obraz terytoria, Gdańsk 2006.

Franco Cristiana (2014), Shameless: The Canine and the Feminine in Ancient Greece, University of California Press, Oakland, CA [USA].

Fuchs Thomas (2017), Self Across Time: the Diachronic Unity of Bodily Existence, „Phenomenology and the Cognitive Sciences”, vol. 16, s. 291-315.

Gallagher Shaun (2005), How the Body Shapes the Mind, Clarendon, Oxford [Wielka Brytania].

Gärtner Christian (2013), Cognition, Knowing and Learning in the Flesh: Six Views on Embodied Knowing in Organization Studies, „Scandinavian Journal of Management”, vol. 29, s. 338-352.

Gehlen Arnold (1986), Der Mensch. Seine Natur und seine Stellung in der Welt, Aula Verlag, Wiesbaden [Niemcy].

Gilman Sander L. (2003), Die Ängste des jüdischen Körpers. Aus Anlass der unwiderstehlichsten Kafka-Biografie, die es bis heute gibt: Reiner Stack lehrt uns, ein Genie neu zu lesen, „Literaturen”, vol. 1/2, s. 2-18.

Gozo Zeno (2015), Interiority and Exteriority: Searching for the Self, „Philobiblon”, vol. 20 (7), s. 319-333.

Haraway Donna (2007), When Species Meet, University of Minnesota Press, Minneapolis [USA].

Holland Norman N. (2009), Literature and the Brain, The PsyArt Foundation, Gainesville, FL [USA].

Husserl Edmund (1973), Zur Phänomenologie der Intersubjektivität II, Martinus Nijhoff, Den Haag [Holandia].

Hutcheon Linda (1980). Narcissistic Narrative. The Metafictional Paradox, Wilfried Laurier University Press, Waterloo (Ontario) [Kanada].

Jonas Hans (1966), The Phenomenon of Life. Toward a Philosophical Biology, Harper \& Raw, New York [USA]. 
Jonas Hans (2016), Imagination and Mind, w: tegoż, Organism and Freedom. An Essay in Philosophical Biology, red. Jens Ole Beckers, Florian Preußger, KGA, t. I/4, Rombach Verlag, Freiburg [Niemcy]. Joraschky Peter, Arnold Stefan (1998), Die Messung der Körper- und

Selbstgrenzen mit dem Rorschach-Test, w: Körperleben in der

Schizophrenie, red. Frank Röhricht, Stefan Priebe, Hogrefe,

Göttingen [Niemcy].

Jung Carl Gustav (1974), Aus dem Gesamtwerk ausgewählt von Jolande Jacobi, Ex Libris, Zürich [Szwajcaria].

Kafka Franz (1994), Przemiana, przeł. Juliusz Kydryński, w: tegoż,

Dzieła wybrane, przeł. Roman Karst, Alfred Kowalkowski, Juliusz

Kydryński, Elżbieta Ptaszyńska-Sadowska, PIw, Warszawa.

Keller Pierre (2001), Kant and the Demands of Self-Consciousness,

Cambridge University Press, Cambridge [Wielka Brytania].

Koch Christof (2012), Consciousness: Confessions of a Romantic

Reductionist, The мiт Press, New York [USA].

Kosik Karel (1994), Das Jahrhundert der Grete Samsa. Von der Möglichkeit oder Unmöglichkeit des Tragischen in unserer Zeit, w: Kafka und Prag, red. Kurt Krolop, Hans D. Zimmermann, Walter de Gruyter, Berlin [Niemcy], s. 187-198.

Kurzweil Ray (2012), How to Create a Mind - the Secret of Human

Thought Revealed, Viking, New York [USA].

Latimer Joanna (2009), Unsettling Bodies. Frida Kahlo's Portraits and Individuality, w: Un/Knowing Bodies, red. Joanna Latimer, Michael Schillmeier, Blackwell Publishing, Malden MA [USA].

Lingis Antonio (2005), Body Transformations, Routledge, New York [USA].

Longrigg James (1988), Anatomy in Alexandria in the Third Century BC, „British Journal of the History of Science”, vol. 21, s. 455-488.

Longrigg James (1993), Greek Rational Medicine. Philosophy and Medicine from Alcmaeon to the Alexandrians, Routledge, London [Wielka Brytania].

Maturana Humberto R., Varela Francisco J. (2012), Der Baum

der Erkenntnis. Die biologischen Wurzeln menschlichen Erkennens, przeł. Kurt Ludewig, Fischer Verlag, Frankfurt am Main [Niemcy].

Merleau-Ponty Maurice (1964), The Primacy of Perception, Northwestern University Press, Evanston, Illinois [USA].

Merleau-Ponty Maurice (2001), The Incarnate Subject. Malebranche, Biran and Bergson on the Union of Body and Soul, red. Paul B. Milan, wstęp Jacques Taminiaux, Humanity Books Prometheus Books, New York [USA]. 
Müller Klaus E. (1996), Der Krüppel. Ethnologia passionis humanae, Verlag C.H. Beck, München [Niemcy].

Nabokov Vladimir (1980), Lectures on Literature. Franz Kafka:

The Metamorphosis, w: Lectures on Literature, red. Fredson Bowers, Harcourt Brace Jovanovich, San Diego [USA].

Nida-Rümelin Martina (2007), Der Blick von innen. Zur transtemporalen Identität bewusstseinsfähiger Wesen, Suhrkamp, Frankfurt am Main [Niemcy].

Nietzsche Friedrich (1995), Tako rzecze Zaratustra, przeł. Wacław Berent, Zysk i S-ka, Poznań.

Nowak Ewa (2017), „Ustrój cielesny” w doświadczeniu podmiotowym i międzypodmiotowym, „Filozofia i Nauka”, t. 5, s. 61-87.

Platon (1958), Państwo, przeł. Władysław Witwicki, PWN, Warszawa.

Ratcliffe Matthew (2007), Feelings of Being. Phenomenology, Psychiatry, and the Sense of Reality, Oxford University Press, Oxford [Wielka Brytania].

Renehan Robert (1981), The Meaning of Soma in Homer, „California Studies in Classic Antiquity", vol. 12, s. 269-282.

Ricoeur Paul (1991), Life in Quest of Narrative, w: On Paul Ricoeur, red. David Wood, Routledge, London [Wielka Brytania], s. 20-33.

Rocca Julius (2003), Galen on the Brain, Brill, Leiden [Holandia].

Roth Gerhard, Strüber Nicole (2016), Wie das Gehirn die Seele macht, Klett-Cotta Verlag, Stuttgart [Niemcy].

Scheler Max (1987), Stanowisko człowieka $w$ kosmosie, przeł. Adam Węgrzecki, w: tegoż, Pisma z antropologii filozoficznej i teorii wiedzy, PWN, Warszawa.

Schüller Marco (2010), Das archaische Gehirn, w: Neuroästhetik.

Perspektiven auf ein interdisziplinäres Forschunsgebiet, red. Karin Herrmann, Kassel University Press, Kassel [Niemcy].

Shusterman Richard (2012), Myślenie poprzez ciato. Rozwinięcie nauk humanistycznych - uzasadnienie dla somaestetyki, przel. Sebastian Stankiewicz, w: Wielozmystowość. Filozofia i dydaktyka, red. Aneta Grodecka, Anna Podemska-Kałuża, Wydawnictwo Naukowe UAM, Poznań.

Snell Bruno (2009), Odkrycie ducha. Studia o greckich korzeniach europejskiego myślenia, przeł. Agna Onysymow, Fundacja Aletheia, Warszawa.

Swindel J.S. (2007), Facial Allograft Transplantation, Personal Identity, and Subjectivity, "Journal of Medical Ethics”, vol. 33, s. 449-493.

Todorov Tzvetan (2000), Race and Racism, w: Theories of Race and Racism, red. Les Back, John Solomos, Routledge, London [Wielka Brytania]. 
Turkle Sherry (2006), The Second Self, мiт Press, New York [uSA]. Waal Frans de (2013), Matpy i filozofowie. Skąd pochodzi moralność?, przeł. Bartosz Brożek, Michał Furman, Copernicus Center, Kraków.

Waldenfels Bernhard (2013), Das leibliche Selbst. Vorlesungen zur Phänomenologie des Leibes, Suhrkamp, Frankfurt am Main [Niemcy]. Wiener Norbert (1990), God and Golem, The MIT Press, Cambridge

[Wielka Brytania].

\section{Ewa Nowak}

\section{Todd's Identity. The Brain Between Neurosphere and the Literary (Meta)Fiction}

The paper explores hybrid identities of main characters in chosen contemporary authors as Kafka, Dürrenmatt, Bulgakov, Dukaj, and in particular Brown. They all contribute to the posthumanist literary genre and to better comprehension of condition posthumana as a leading utopia in the age of advanced technologies. The author argues for affinities between the human and the non-human brain, far beyond the anthropocentrism and anthropodenialism controversy.

Keywords: brain; body/mind relation; hybrid identity; posthumanism; Kafka; Dürrenmatt; Bulgakov; Brown; Dukaj; phenomenology.

Ewa Nowak - profesor zwyczajny, filozof i etyk, kieruje Zakładem Etyki Instytutu Filozofii Uniwersytetu im. Adama Mickiewicza w Poznaniu, autorka i redaktorka kilkunastu książek (ostatnio: Experimental Ethics, Educating Competencies for Democracy, Kohlberg Revisited, 2018; w przygotowaniu: Advancing the Human Self. Do Technologies Make Us "Posthuman"?), redaktor naczelna czasopisma naukowego „Ethics in Progress”. Prowadziła badania między innymi na Uniwersytecie Cornella, uniwersytetach w Konstancji i Bernie, Uniwersytecie Humboldtów w Berlinie i Universität-GH Siegen. Zainteresowania badawcze: etyka i filozofia praktyczna, kognicja moralna, antropologia vs. technologia. Numer ORCID: 0000-0002-5722-7711. 